\title{
SISTEM INFORMASI AKADEMIK SMP ANGKASA LANUD HUSEIN SASTRANEGARA BANDUNG
}

\author{
Dody Destriady ${ }^{1)}$, R.Fenny Syafariani ${ }^{2)}$ \\ Program Studi Sistem Informasi ${ }^{1)}$, Fakultas Teknik dan Ilmu Komputer ${ }^{2)}$ \\ Universitas Komputer Indonesia ${ }^{12)}$ \\ dodydestriady@gmail.com ${ }^{1)}, \underline{\text { r.fenny.syafariani@email.unikom.ac.id }}{ }^{2)}$
}

\begin{abstract}
ABSTRAK
Sistem Informasi Akademik merupakan sistem yang dapat memeberikan informasi yang didapat dari hasil pengolahan data akademik. Penting adanya sistem informasi bagi sekolah. Dalam hal ini, SMP Angkasa dijadikan tempat penelitian, karena sistem yang kini digunakan belum terkelola dengan baik sehingga seringkali mempersulit dalam penyelesaian prosedur - prosedur akademik yang ada seperti, pendaftaran, pengelolaan data siswa, pembagian kelas, penjadwalan, penilian, absensi, dan pembayaran SPP atau PPDB. Tujuan dari penelitian ini adalah untuk mengembangkan prosedur baru yang terkomputerisasi.

Metode pendekatan yang digunakan adalah terstruktur dan metode pengembangan Waterfall. Desain penelitian menggunakan metode deskriptif dan kuantitatif. Metode pengumpulan data menggunakan teknik wawancara, observasi, dan studi litelatur. Alat bantu penelitian yang digunakan untuk menggambarkan sistem pada aplikasi ini yaitu flow map, diagram konteks, dfd, kamus data, dan perancangan basis data. Aplikasi ini dibuat menggunakan bahasa pemrograman JAVA dan database MySql.

Perangkat lunak yang dihasilkan diberi nama SIAKSA. SIAKSA diharapkan dapat memberikan kemudahan bagi guru dalam menyelesaikan prosedur akademis, serta meminimalisir terjadinya kesalahan dalam pencatatan data dan membuat data tersebut menjadi terintregasi, aman dan terjamin.
\end{abstract}

Kata kunci : prosedur, akademis, sistem informasi, Java

\section{PENDAHULUAN}

\subsection{Latar Belakang Penelitian}

Sistem Informasi merupakan suatu teknologi yang fungsinya yaitu untuk mengolah suatu dan menjadikan sebuah Informasi untuk diberikan kepada penggunanya. Data tersebut didapatkan baik dari penggunanya langsung atau dari pihak ketiga, data itu sendiri merupakan fakta fakta yang belum memiliki nilai atau arti. Dari penjelasan Sistem Informasi tersebut, maka banyak pekerjaan yang dapat menggunakan fungsi dari Sistem Informasi tersebut. Sistem Informasi yang saat ini ada, digunakan oleh organisasi yang mampu secara materil untuk membeli Sistem Informasi tersebut, seperti Hotel, Toko, Sekolah, dan organisasi lainya. Contoh sekolah menerapkan Sistem Informasi untuk mengolah data nilai siswa yang kemudian dijadikan Informasi berupa raport.

Sekolah setiap tahunya akan membuka pendaftaran dan meluluskan siswanya. Dimulai dengan pendaftaran, calon siswa tersebut akan menjalani serangkaian prosedur, untuk Negeri umumnya terdapat penyeleksian seperti nem atau pun tes, sedangkan swasta tidak terdapat penyeleksian. Kemudian setelah calon siswa diterima, pihak sekolah akan melakukan pembagian kelas dimana pembagian kelas tersebut memiliki beberapa indikator seperti asal sekolah, nama, dan lainya. Kemudian terbitlah absensi sesuai dengan pembagian kelas tersebut, kemudian dari absensi tersebut dapat ditentukan jadwal melakukan SPP. Sekolah kemudian membuat jadwal pembelajaran pertingkat yaitu 1, 2, 3, dan seterusnya. Dalam pembelajaran setiap guru diwajibkan memberikan nilai untuk mata pelajaran pada akhir semester, dari nilai tersebut akan menentukan keputusan bahwa siswa tersebut naik/lulus atau gagal/harus mengulang.

Dari penelitian yang dilakukan di Sekolah Swasta yaitu SMP Angkasa Lanud Husein Sastranegara, yang berlokasi di Jl. Pajajaran no.151. Kel. Husein sastranegara, Kec. Cicendo, Jawa Barat, Bandung, ini juga menggunakan prosedur yang serupa. Beberapa dari prosedur tersebut cukup menyita waktu 
guru dari kesibukan pekerjaan yang lainya. Siswa di SMP Angkasa di bagi menjadi beberapa kategori diantaranya :

\begin{tabular}{|c|c|c|}
\hline 1. & Kategori 1 & $=$ UMUM \\
\hline 2. & Kategori 2 & $=$ Putra/Putri TNI AU $/$ \\
\hline Bintara & & \\
\hline $\begin{array}{l}3 . \\
\text { Perwira }\end{array}$ & Kategori 3 & $=$ Putra/Putri TNI AU $/$ \\
\hline 4. & Kategori 4 & Putra/Putri \\
\hline
\end{tabular}

Masing - masing kategori tersebut memiliki perbedaan dalam biaya sekolahnya tergantung ketentuan dari pihak sekolah. Siswa disortir sesuai kategori tersebut ketika melakukan pendaftaran penerimaan siswa baru.

Dimulai dari prosedur pendaftaran yang digunakan di SMP Angkasa, yaitu sekolah membuka pendaftaran di lingkungan sekolah, kemudian calon siswa mendaftar langsung ke loket pendaftaran yang terletak di lingkungan sekolah dengan menyertakan persyaratan yang di tentukan dan mengisi formulir yang diberikan oleh petugas pendaftaran. Kemudian pihak sekolah mencatat pendaftar dan menuliskan nomor pendaftaran secara manual, pendaftaran akan ditutup apabila kuota yang tersedia di SMP Angkasa telah mencukupi. Setelah menjalani pendaftaran siswa otomatis di terima di SMP Angkasa, pihak sekolah akan menghubungi para orang tua siswa bahwa siswa tersebut diterima. Data pendaftar tersebut kini berubah menjadi data siswa tingkat 1 , data siswa tingkat 1 tersebut selanjutnya akan digunakan untuk melakukan pembagian kelas. pembagian kelas di SMP Angkasa dilakukan setiap tahun ajaran baru dengan kata lain setiap kelas pada tingkat 1 setelah naik pada tingkat 2 kelasnya akan dibagi kembali sesuai dengan data siswa tingkat 2 , begitu juga dengan tingkat 2 ke tingkat 3 dan pendaftar yang telah diterima di SMP Angkasa. Pemabgian kelas di SMP Angkasa sendiri melalui beberapa proses dengan indikator - indikator yang telah ditentukan, indikator tersebut antara lain Nem, asal sekolah untuk siswa yang baru diterima menjadi kelas 1, Nama, jenis kelamin, peringkat, dll. Setiap indikator yang telah ditentukan tidak boleh ada kesamaan pada setiap kelas yang dibagi, contoh siswa bernama Mohammad pada kelas 1A diusahakan tidak boleh ada siswa dengan nama yang sama, apabila terpaksa harus sama maka nama akhirnya menjadi patokan dalam pembagian kelas. Proses tersebut dilakukan oleh pihak sekolah dengan menyortir secara satu per satu oleh satu orang guru yang diperintahkan kepala sekolah baik itu kelas 1,2, dan 3 .

Setelah pembagian kelas selesai maka lanjut kepada prosedur selanjutnya yaitu menentukan jadwal pembayaran SPP perbulan serta penjadwalan mata pelajaran. Hasil dari pembagian kelas adalah absensi siswa perkelas, dari absensi ini lah pihak sekolah dapat memantau pembayaran siswa SPP, absensi ini juga dijadikan indikator untuk melakukan proses penjadwalan mata pelajaran.

Prosedur penjadwalan ini memiliki beberapa indikator antara lain, Jam pelajaran, Kelas, dan pengajuan Jam guru. Maksud dari pengajuan jam guru adalah setiap guru diberikan jatah oleh pihak sekolah berupa jam jam yang tidak bisa mengajar. Dari indikator indikator tersebut guru yang diperintahkan untuk membuat jadwal mata pelajaran, mengawali prosesnya dengan melihat pengajuam jam guru, kemudian menentukan jam guru tersebut mengajar, setiap mata pelajaran tidak boleh ada guru dan jam yang sama pada kelas yang berbeda. Di SMP Angkasa ini terdapat 2 bagian jam masuk jam pagi yaitu untuk kelas tingkat 3 dan 2, kemudian jam siang untuk kelas tingkat 2 dan 1, untuk kelas 2 mendapatkan jadwal masuk sekolah pagi dan siang, dimana kelas 2 yang masuk pagi setelah akhir semester ganjil akan dipindahkan ke jam siang, begitupun sebaliknya. Dari jadwal yang telah berhasil terbentuk, maka setiap guru yang mengajar mata pelajaran dengan kelas yang di ajar, dapat memasukan nilai ketika proses pembelajaran selama berlakunya jadwal tersebut. Nilai ini dicatat oleh guru sesuai kelas yang diajarnya, ketika akhir semester guru tersebut memberikan hasil rekapan nilai kepada wali kelas yang kemudian akan dibuat dalam raport setiap siswa. Raport ini berisikan nilai nilai yang didapat siswa permata pelajaran serta deskripsi dari kelakuan siswa tersebut dilingkungan sekolah, serta keputusan naik tidaknya siswa.

Kepala sekolah membutuhkan laporan untuk dapat membuat keputusan untuk keberlangsungan sekolah, laporan tersebut didapat dari beberapa prosedur yang telah dijelaskan diatas. Laporan ini dapat berupa laporan keuangan, laporan kesiswaan, dan laporan pendaftar. Kepala sekolah untuk mendapatkan laporan harus meminta terlebih dahulu kepada guru yang bersangkutan yang 
diberikan kewenangan untuk memegang setiap prosedur akademik tersebut.

Sesuai dengan hasil dari penelitian di SMP Angkasa Lanud Husein Sastranegara, peneliti menemukan beberapa prosedur yang dinilai kurang efektif dalam pelaksanaanya. Oleh karena itu peneliti mengusulkan membuat sebuah Sistem Informasi berbasis komputer yang saling terintregasi guna untuk meningkatkan efektifitas, dan memaksimalkan prosedur yang telah ada. Usulan tersebut akan disajikan dalam penelitian dengan judul "SISTEM INFORMASI AKADEMIK SMP ANGKASA LANUD HUSEIN SASTRANEGARA BANDUNG".

\subsection{Identifikasi Dan Rumusan Masalah \\ 1.2.1. Identifikasi Masalah}

Berdasarkan latar belakang penelitian yang telah diuraikan diatas, maka peneliti dapat mengidentifikasi masalah yang sedang dihadapi, sebagai berikut:

1. Prosedur - prosedur yang diterapkan di SMP Angkasa, seperti prosedur pendaftaran peserta didik baru, pembagian kelas, penjadwalan mata pelajaran, perhitungan nilai, perhitungan pembayaran SPP dan cicilan PPDB, serta pembuatan laporan dilakukan secara manual, dan dikerjakan oleh orang yang berbeda.

2. Data yang didapat dari hasil prosedur yang dilakukan belum disediakan media penyimpanan yang saling berintregasi antar prosedur tersebut. Hal ini dinilai kurang efektif dan efisien, karena data tersebut disimpan dalam dokumen biasa tanpa adanya Database.

3. Karena prosedur yang dilakukan tanpa menggunakan aplikasi khusus serta tanpa disediakanya Database, maka data tidak konsisten serta kesamaan data atau redundancy data dapat terjadi, karena setiap prosedur yang ada dikerjakan oleh orang yang berbeda.

\subsubsection{Rumusan Masalah}

Dari permasalahan yang telah teridentifikasi, selanjutnya akan ditentukan rumusan masalahnya, yaitu:

Bagaimana merancang sebuah aplikasi yang saling terintregasi, untuk dapat digunakan dalam pengolahan data di SMP Angkasa.

\subsubsection{Maksud Penelitian}

Maksud dilakukan penelitian ini adalah untuk memaksimalkan prosedur di SMP Angkasa yang saat ini masih dilakukan secara manual, dengan membuat sistem informasi secara tekomputerisasi dan teringtregasi untuk mempermudah mendapatkan informasi, mempermudah pekerjaan, dan meminimalisir kesalahan.

\subsubsection{Tujuan Penelitian}

Tujuan yang ingin dicapai dalam penelitian ini adalah untuk memaksimalkan prosedur di SMP Angkasa yang masih dilakukan dengan manual, dengan membuat suatu sistem informasi berbasis desktop untuk mengerjakan prosedur tersebut lebih efektif dan efisien. Berikut akan dijelaskan lebih mendetail dari tujuan tersebut :

1. Untuk mengetahui bagaimana proses dari setiap prosedur yang sedang di SMP Angkasa Lanud Husein Sastranegara. Dengan melakukan observasi secara langsung serta wawancara dengan pihak sekolah.

2. Untuk dapat membuat sistem informasi yang mengintregasikan antar prosedur yang ada. Sistem informasi tersebut berbentuk aplikasi yang dapat dioperasikan dengan mudah dan cepat oleh guru, yang mampu menyelesaikan tugas dengan lebih effektif dan efisien. Setiap tugas tersebut memiliki beberapa indikator yang telah disepakati. Sistem ini juga mampu membuat laporan untuk kepala sekolah menentukan keputusan yang akan di ambil demi keberlangsungan sekolah.

3. Untuk melakukan pengujian sistem informasi akademik di SMP Angkasa.

4. Untuk mengimplementasikan sistem informasi akademik di SMP Angkasa.

\subsection{Kegunaan Penelitian}

Terdapat 2 kegunaan penelitian antara lain kegunaan praktis serta kegunaan akademis, berikut adalah kegunaanya :

\subsubsection{Kegunaan Praktis}

Bagi SMP Angkasa Lanud Husein Sastranegara, hasil dari penelitian ini semoga dapat berguna untuk meningkatkan effektifitas tugas guru serta akademis.

Bagi peneliti, seluruh rangkaian kegiatan dan hasil penelitian diharapkan dapat lebih memantapkan penguasaan ilmu sistem

\subsection{Maksud Dan Tujuan Penelitian}


informasi yang telah dipelajari di UNIKOM bandung.

\subsubsection{Kegunaan Akademis}

Bagi perguruan tinggi, hasil penelitian ini diharapkan dapat menjadi dokumen akademik yang berguna untuk mahasiswa lain yang menjalani mata kuliah skripsi atau sebagai acuan bagi yang membutuhkan.

\subsection{Batasan Masalah}

Untuk dapat mencapai sasaran dalam melakukan penelitian ini, maka permasalahan akan dibatasi sebagai berikut :

1. Penelitian ini membahas mengenai pengolahan data yang meliputi, PPDB (Pendaftaran Peserta Didik Baru), pembagian kelas, penjadwalan mata pelajaran, perhitungan pembayaran SPP, perhitungan Nilai, serta laporan keuangan dari prosedur - prosedur tersebut.

2. Perangkat lunak yang dihasilkan berupa perangkat lunak offline,

3. Penelitian ini dirancang dengan metode pendekatan terstruktur dengan metode pengembangan Waterfall,

4. Aplikasi dari hasil penelitian ini berbasis desktop dengan bahasa pemrograman JAVA dan Database MySql.

\subsection{Pengertian Sistem}

II. KAJIAN PUSTAKA

Sistem adalah hubungan satu unit dengan unit-unit lainnya yang saling berhubungan satu sama lainnya dan yang tidak dapat dipisahkan serta menuju satu kesatuan dalam rangka mencapai tujuan yang telah ditetapkan. [2]

\subsection{Pengertian Informasi}

Informasi adalah data yang telah diproses atau diolah kedalam bentuk yang berarti untuk penerimanya dan merupakan nilai yang sesungguhnya atau dipahami dalam tindakan atau keputusan yang sekarang atau nantinya. [2]

\subsection{Pengertian Sistem Informasi}

Sistem informasi yang dikutip dari buku yakub pengantar sistem informasi adalah sistem informasi merupakan kombinasi teratur dari orang-orang, perangkat keras (hardware), perangkat lunak (software), jaringan komunikasi, dan sumber daya data yang mengumpulkan, mengubah,dan menyebarkan informasi dalam sebuah organisasi. [6]

\subsection{Komponen Sistem Informasi}

Komponen system informasi sebagai berikut:

a. Input

Semua data yang dimasukan ke dalam system informasi, dalam hal ini yang dimaksud adalah dokumen, formulirformulir,dan file-file

b. Proses

Proses merupakan kumpulan prosedur yang akan memanipulasi input yang kemudian akan disimpan dalam basisdata dan seterusnya

c. Output

Merupakan semua keluaran atau hasil dari model yang sudah diolah menjadi suatu informasi yang berguna dan dapat dipakai penerima. [4]

\subsection{Pengertian Akademik}

pengertian akademik adalah keadaan orang-orang bisa menyampaikan dan menerima gagasan, pemikiran, ilmu pengetahuan, dan sekaligus dapat mengujinya secara jujur, terbuka, dan leluasa. [1]

\subsection{Pengertian Sistem Informasi \\ Akademik}

Dikutip dari buku Sistem informasi akademik dapat diartikan aplikasi untuk membantu memudahkan pengelolaan data-data dan informasi yang berkaitan dengan instansi pendidikan. [3]

\subsection{Objek Penelitian}

\section{OBJEK DAN METODE PENELITIAN}

Objek penelitian adalah suatu atribut atau sifat nilai dari orang, objek atau kegiatan yang mempunyai variasi tertentu yang ditetapkan oleh peneliti untuk dipelajari dan kemudian ditarik kesimpulan. Objek dari penelitian "Sistem Informasi Akademik SMP Angkasa Lanud Husein Sastranegara Bandung", ini adalah SMP Angkasa Lanud Husein Sastranegara Bandung. Untuk melengkapi objek penelitian ini akan diuraikan sejarah, visi dan misi, profil sekolah, Struktur organisasi dan deskripsi tugas. [5]

\subsection{Metode Penelitian \\ 3.2.1. Desain penelitian}


Metode penelitian yang digunakan adalah metode deskriptif dan kuantitatif. Deskriptif merupakan penelitian yang dilakukan untuk mengetahui nilai variable mandiri, baik satu atau lebih variable (independen) tanpa membuat perbandingan, atau menghubungkan dengan variable lain. Sedangkan kuantitatif adalah penelitian dengan memperoleh data yang berbentuk angka atau data kualitatif yang diangkakan.

\subsubsection{Jenis dan Metode Pengumpulan Data}

\subsubsection{Sumber Data Primer}

Metode pertama yang digunakan dalam penelitian ini adalah observasi. Observasi adalah sebuah metode atau teknik yang dilakukan untuk mengumpulkan data dengan cara melakukan pengamatan secara langsung. pengamatan yang dilakukan oleh peneliti di SMP Angkasa adalah untuk mengetahui permasalahan - permasalahan yang sebenarnya atau sedang terjadi yang berhubungan dengan pembahasan yang akan diteliti.

Metode penelitian yang digunakan kedua adalah Wawancara. Peneliti melakukan pengumpulan data dengan mengajukan beberapa pertanyaan kepada pihak yang telah ditentukan oleh SMP Angkasa, pertanayaan tersebut berhubungan dengan pembahasan yang sedang diteliti.

\subsubsection{Sumber Data Sekunder}

Kemudian data lain yang digunakan adalah sumber data sekunder. Sumber data sekunder, merupakan data yang diperoleh dari sumber lain seperti dokumen perusahaan atau dengan melakukan study litelatur lewat media internet atau dari buku bacaan, karya ilmiah dengan disertakan sumber tersebut dalam penelitian ini. Adapun dokumen yang telah diberikan oleh pihak sekolah untuk dilakukan penelitian antara lain Data siswa tahun ajaran 2015 / 2016, data guru, profil sekolah, dan dokumen lainya.

\subsubsection{Metode Pendekatan Dan \\ Pengembangan Sistem}

\subsubsection{Metode Pendekatan Sistem}

Metode yang digunakan dalam penelitian ini yaitu metode pendekatan terstruktur, metode ini menggunakan alat-alat serta teknik dalam melakukan pendekatan untuk melakukan pengembangan sistem yang terstruktur. Tujuan dari metode ini adalah untuk membuat sebuah sistem yang dikembangkan dapat lebih mudah dipahami dan sesuai dengan komponen - komponen yang telah ditentukan.

\subsubsection{Metode Pengembangan Sistem}

Metode pengembangan sistem informasi akademik ini menggunakan metode sekuensial linier (waterfall). Metode Waterfall merupakan metode pengembangan sistem yang sistematik dan sekuensial yang mulai pada tingkat dan kemajuan sistem sampai pada analisis, desain, kode, test, dan pemeliharaan. Berikut adalah gambaran dari model Waterfall.

\subsubsection{Alat Bantu Analisis Perancangan}

Alat tersebut berupa Data Flow

Diagram (DFD), Flow Map, Kamus Data, Tabel relasi, dan diagram konteks.

\subsubsection{Evaluasi Sistem Yang Berjalan}

Dari analisis tersebut dilakukan evaluasi sebagai yaitu.

\section{Table 3-1: Evaluasi Sistem Yang Berjalan}

\begin{tabular}{|c|c|c|}
\hline No. & Masalah & $\begin{array}{l}\text { Usulan } \\
\text { Permasalahan }\end{array}$ \\
\hline 1 & $\begin{array}{l}\text { Prosedur - prosedur yang } \\
\text { diterapkan di SMP } \\
\text { Angkasa, seperti } \\
\text { prosedur pendaftaran } \\
\text { peserta didik baru, } \\
\text { pembagian kelas, } \\
\text { penjadwalan mata } \\
\text { pelajaran, perhitungan } \\
\text { nilai, perhitungan } \\
\text { pembayaran SPP, serta } \\
\text { pembuatan laporan } \\
\text { dilakukan secara manual, } \\
\text { dan dikerjakan oleh } \\
\text { orang yang berbeda. }\end{array}$ & $\begin{array}{l}\text { Perlunya suatu } \\
\text { aplikasi } \\
\text { pengolahan data } \\
\text { yang akurat, } \\
\text { terintegrasi dalam } \\
\text { satu penyimpanan } \\
\text { data, dan dapat } \\
\text { mempercepat } \\
\text { dalam proses } \\
\text { mengelola data } \\
\text { pendaftaran peserta } \\
\text { didik baru, } \\
\text { pembagian kelas, } \\
\text { penjadwalan mata } \\
\text { pelajaran, } \\
\text { perhitungan } \\
\text { pembayaran SPP, } \\
\text { serta pembuatan } \\
\text { laporan }\end{array}$ \\
\hline 2 & $\begin{array}{l}\text { Data yang didapat dari } \\
\text { hasil prosedur yang } \\
\text { dilakukan belum } \\
\text { disediakan media } \\
\text { penyimpanan yang saling } \\
\text { berintregasi antar } \\
\text { prosedur tersebut. Hal ini } \\
\text { dinilai kurang efektif dan } \\
\text { efisien, karena data } \\
\text { tersebut disimpan dalam } \\
\text { dokumen biasa tanpa } \\
\text { adanya Database. }\end{array}$ & $\begin{array}{l}\text { Dibuatkannya } \\
\text { suatu aplikasi yang } \\
\text { dapat } \\
\text { menyelasarkan } \\
\text { antara prosedur } \\
\text { satu dengan } \\
\text { prosedur lainnya } \\
\text { serta terintegrasi } \\
\text { dalam satu } \\
\text { penyimpanan data } \\
\text { (Database) agar } \\
\text { ketika data } \\
\text { diperlukan mudah } \\
\text { untuk diakases }\end{array}$ \\
\hline
\end{tabular}




\begin{tabular}{|l|l|l|}
\hline 3 & Karena prosedur yang & $\begin{array}{l}\text { Perlunya suatu } \\
\text { aplikasi }\end{array}$ \\
& dilakukan tanpa & pengolahan data \\
& menggunakan aplikasi & yang akurat serta \\
& khusus serta tanpa & terintegrasi dalam \\
& disediakanya Database, & satu penyimpanan \\
& maka data tidak & data agar tidak \\
& konsisten serta kesamaan \\
& data atau redundancy & adanya redudancy \\
& data atau kesamaan \\
& data dapat terjadi, karena \\
& setiap prosedur yang ada & data yang \\
& dikerjakan oleh orang & tersimpan. \\
& yang berbeda. & \\
\hline
\end{tabular}

\section{HASIL DAN PEMBAHASAN \\ 4.1. Perancangan Sistem \\ Perancangan sistem dimulai setelah} melakukan tahap analisis dari suatu sistem yang telah berjalan di SMP Angkasa Lanud Husein

Sastranegara Bandung. Perancangan sistem dapat didefinisikan sebagai penggambaran atau tahap membuat sketsa dan atau pengaturan dari beberapa sistem atau elemen terpisah kedalam satu kesatuan sistem yang utuh dan dapat berfungsi sesuai dengan harapan.

\subsubsection{Tujuan Perancangan Sistem}

Perancangan sistem yang dibuat memiliki suatu tujuan yaitu untuk melakukan pengembangan sistem yang telah di analisis sebelumnya. Dalam perancangan sistem ini akan digambarkan suatu rancangan dari prosedur, basis data, antar muka, dan arsitektur jaringan yang akan menjadi panduan dalam tahap pembangunan perangkat lunak, serta rancangan untuk tahapan pengujian perangkat lunak dan implementasi dari sistem atau perangkat lunak yang diusulkan peneliti.

\subsubsection{Gambaran Umum Sistem Yang Diusulkan}

Perangkat Lunak SIAKSA ( Sistem Informasi Akadameik SMP Angkasa ) Lanud Husein Sastranegara Bandung, merupakan perangkat lunak berbasis desktop yang menyediakan fitur untuk membantu para guru dalam menyelesaikan aktifitas atau prosedur akademik si SMP Angkasa. Fitur tersebut antara lain, fitur pendaftaran, fitur penerimaan siswa dengan penentuan NIS secara otomatis, Fitur pembagian kalas dan penentuan wali kelas, fitur penjadwalan mata pelajaran, fitur pembayaran SPP dan Cicilan PPDB, dan fitur penilaian.

\subsubsection{Perancangan Prosedur Yang Diusulkan}

Rancangan sistem yang diusulkan yang mengacu pada analisis yang sedang berjalan. Tujuan dari perancangan sistem adalah untuk mengembangkan sistem lama. Perancangan sistem menggambarkan suatu rancangangan baru dari prosedur, basis data, antar muka, dan arsitektru jaringan. Berikut adalah hasil perancangan sistem informasi akademik SMP Angkasa :

1. Flow Map pembagian kelas

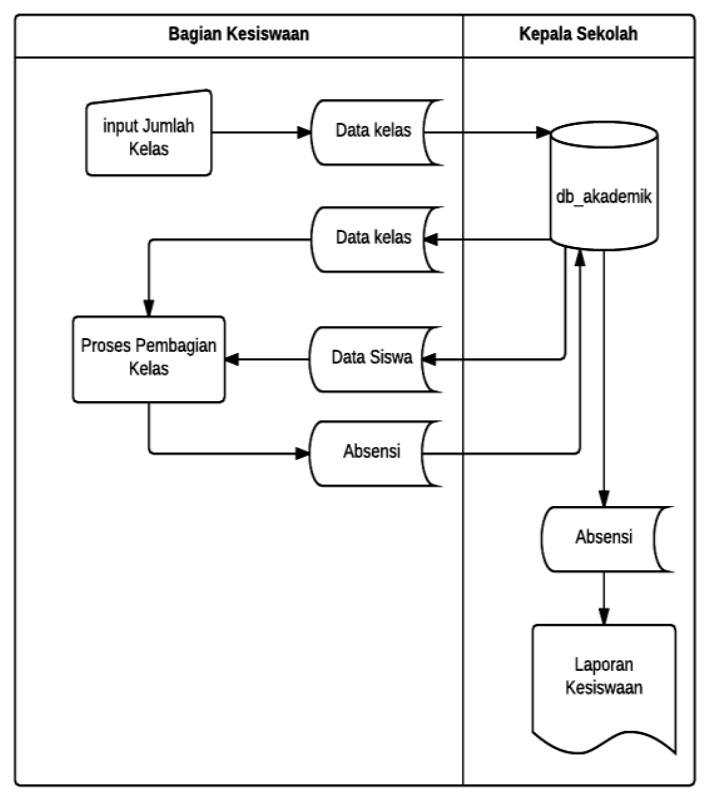

Gambar 4. 1. Flow map usulan prosedur pembagian kelas

2. Flow Map pendaftaran

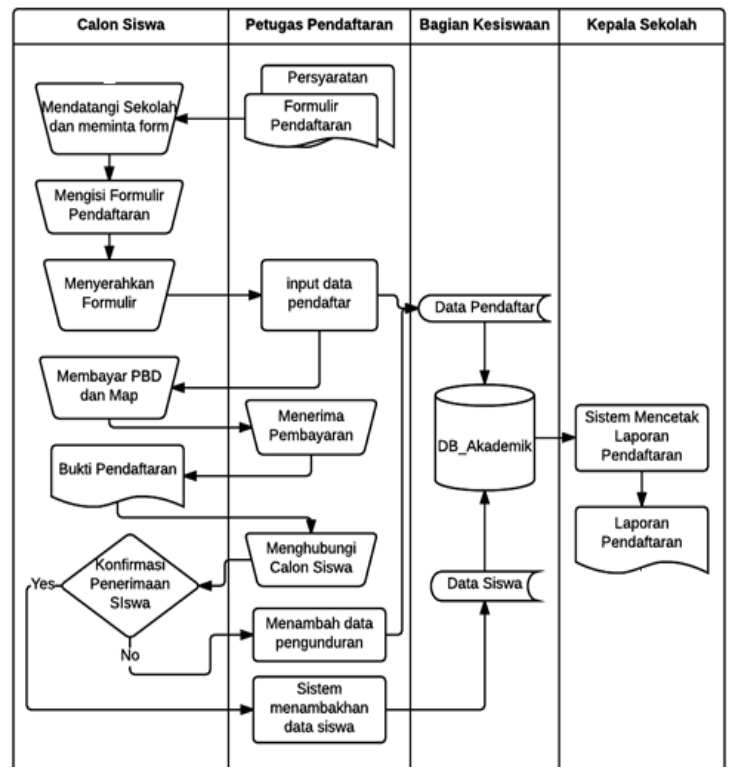

Gambar 4. 2. Flow map usulan prosedur pendaftaran 
3. Flow Map penjadwalan

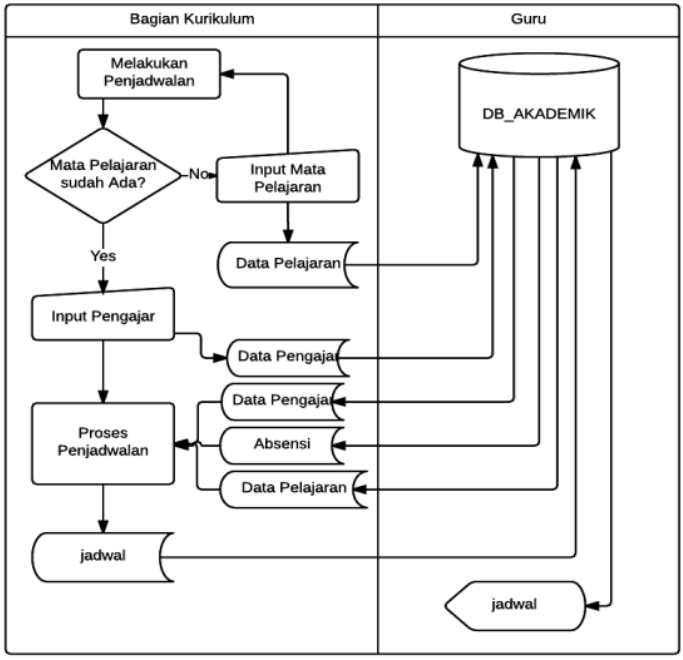

Gambar 4. 3. Flow map usulan prosedur penjadwalan

4. Flow Map Pembayaran

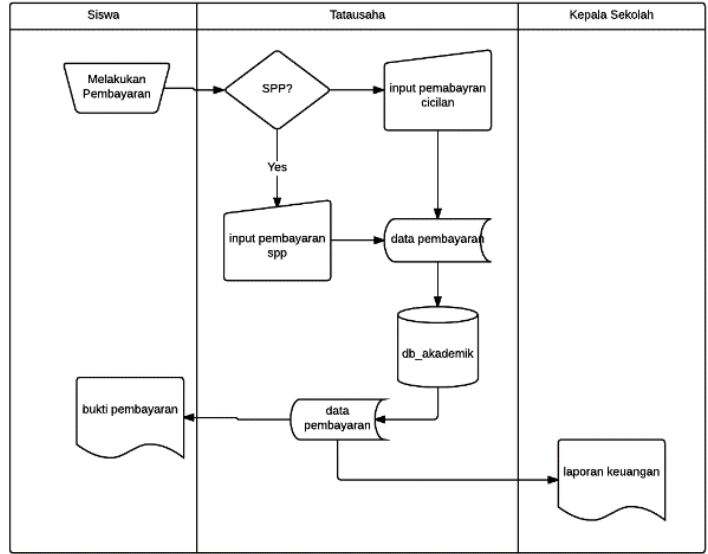

Gambar 4. 4. Flow map usulan prosedur pembayaran

5. Flow Map penilaian

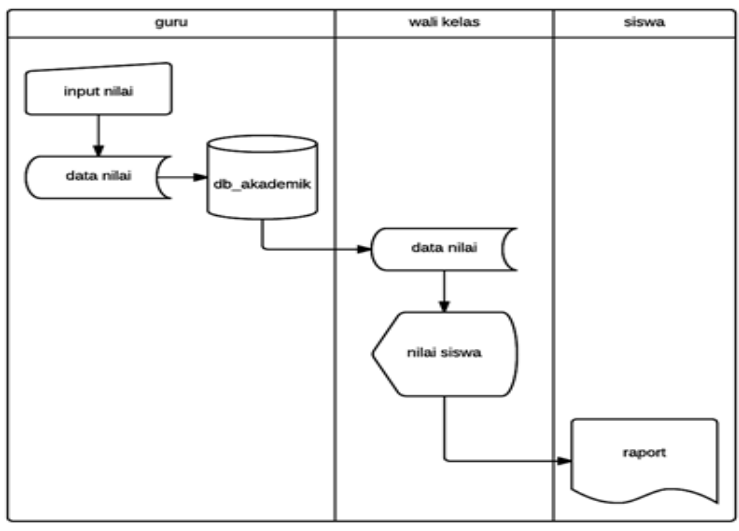

Gambar 4.5. Flow map usulan prosedur penilaian

6. Diagram Konteks

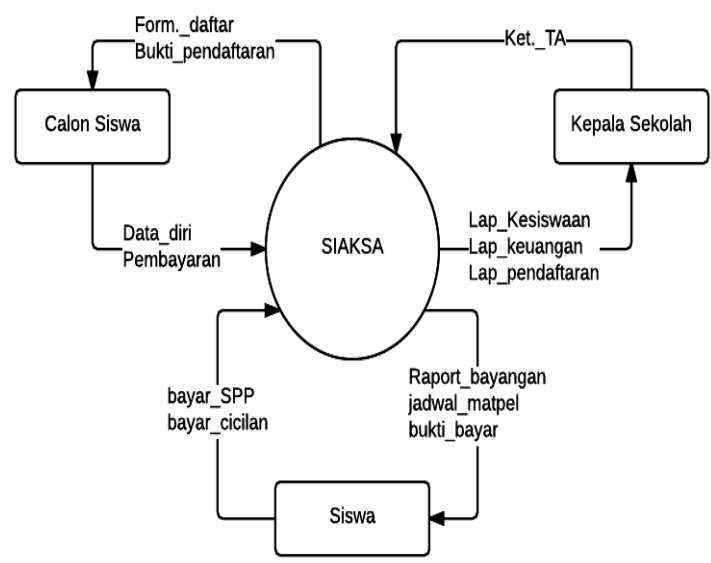

Gambar 4. 6. Usulan Diagram konteks

7. DFD LV1

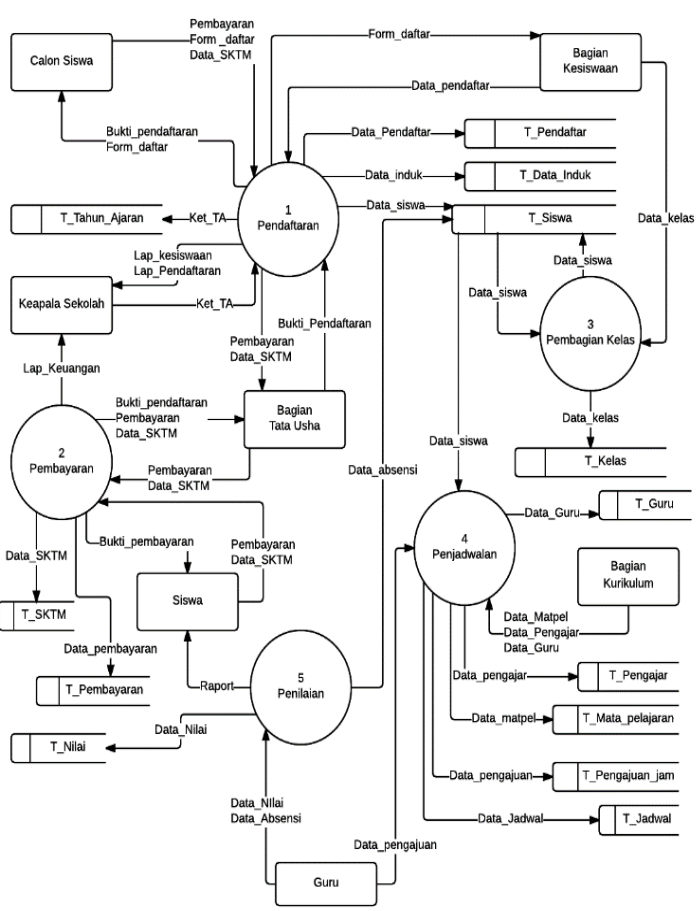

Gambar 4. 7. DFD lv 1 yang diusulkan

Setelah merancang prosedur kemudain melakukan perancangan basis data, rancangan basis data tersebut dilakukan dengan normalisasi data yang didapatkan dari Diagram 
Konteks dan DFD, rancagan tersebut sebegai berikut :

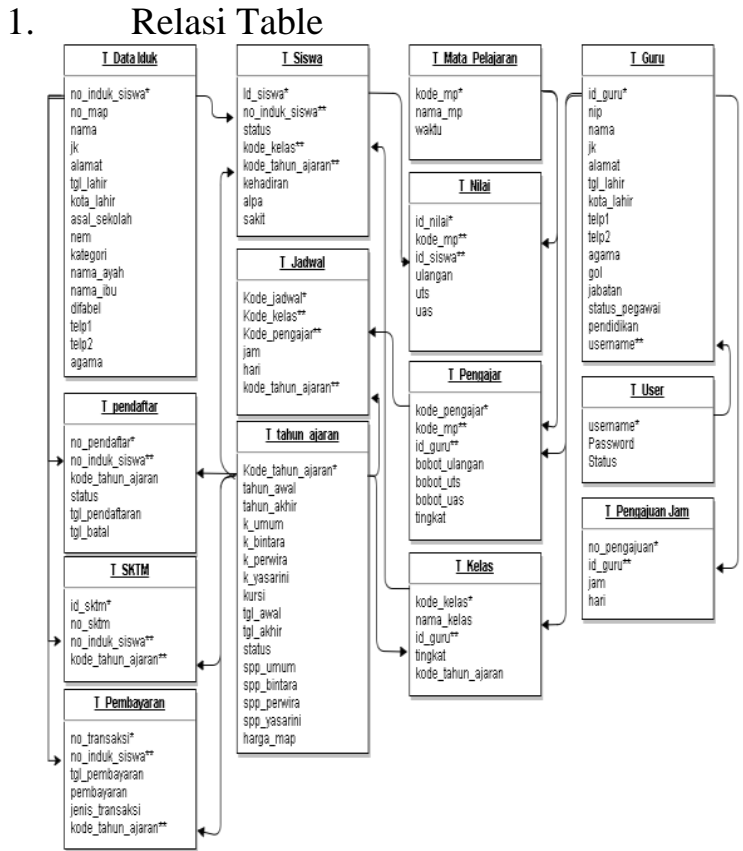

Gambar 4. 8. Relasi tabel

\section{2. $\quad$ ERD}

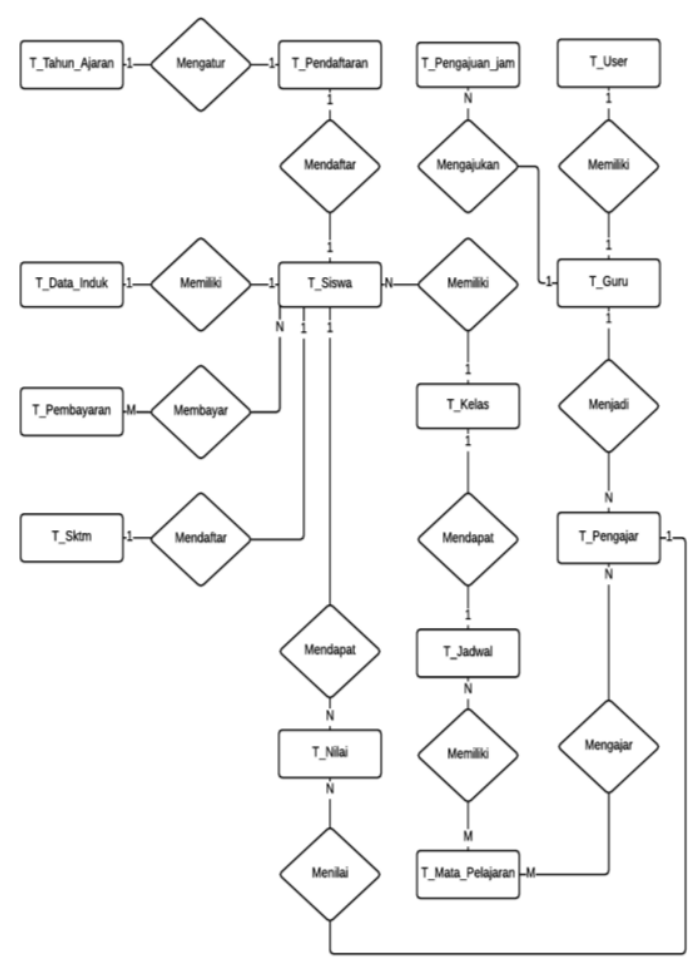

Gambar 4.9. ERD

\section{PENUTUP}

Berdasarkan hasil penelitian yang dilakukan di SMP Angkasa Lanud Husein Sastranegara Bandung, mengenai prosedur prosedur dari sistem akademis yang sedang berjalan, dan teridentifikasi kekurangan yang dapat dianalisis dan dikembangkan lebih lanjut. Oleh karena itu peneliti menyimpulkan penelitian ini sebagai berikut :

1. Prosedur yang dilakukan dapat dikembangkan dengan bantuan perangkat lunak sehingga pekerjaan dapat diselekasikan dengan mudah dan cepat, juga dapat dikerjakan oleh satu orang pengguna.

2. Perangkat lunak tersebut menyediakan database untuk penyimpanan data yang sudah terkomputerisasi

3. Dengan disediakannya database, maka data dari sistem akademis sudah terintregasi antar prosedur, juga data tersebut lebih terjamin.

Dari point - point tersebut maka peneliti mengusulkan sebuah perangkat lunak berbasis desktop yang diberinama SIAKSA (Sistem Informasi Akademik SMP Angkasa) yang diharapkan mampu menutupi kekurangan - kekurangan pada prosedur dari sistem akademis sebelumnya.

\section{DAFTAR PUSTAKA}

[1] Chandra W. Julian, (15 Mei 2016), "Implementasi Sistem Informasi Akademik (Studi Kasus : SMP Negeri 20 Bandung)", 2013, diakses dari (http://profit.is.unikom.ac.id/s/data/jur nal/volume-01/2-julianchandra.pdf/pdf/2-julian-chandra.pdf) UNIKOM, Senin, 1:14 WIB

[2] Goal L Jimmy. "Sistem Informasi Manajemen Pemahaman dan Aplikasi“", Jakarta :PT Grasindo, 2008.

[3] Jogiyanto.Hartono, "Analisis dan Desain Sistem Informasi. Edisi III",Yogyakarta: ANDI, 2010.

[4] Kristanto,Andri. "Perancangan Sistem Informasi dan Aplikasinya". Jakarta, Gava Media, 2013.

[5] Sugiyono. "Metode Penelitian", Bandung, Alfabeta, 2013.

[6] Yakub. "Pengantar Sistem Indormasi", 1st, Yogyakarta: Graha Ilmu, 2012. 